Vukić et al. (2021). Students' perception and attitudes toward faculty image on social networks, International Journal of Cognitive Research in Science, Engineering and Education (IJCRSEE), 9(1), 63-74.

Original scientific paper

UDK:

316.776:077.5(497.11)

378:659.1(497.11)

Received: March, 17.2021.

doi: $10.23947 / 2334-8496-2021-9-1-63-74$
(A) Check for updates

Revised: April, 01.2021.

doi: $10.23947 / 2334-8496-2021-9-1-63-74$
(D) Check for updates

Accepted: April, 13.2021.

\title{
Students' Perception and Attitudes toward Faculty Image on Social Networks
}

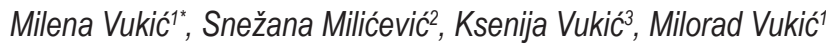 \\ 1Academy of Applied Studies Belgrade, College of Hotel Management, Serbia, e-mail: milena.vukic12@gmail.com; \\ miloradmilovukic@gmail.com \\ 2University of Kragujevac, Faculty of Hotel Management and Tourism in Vrnjačka Banja, Serbia, \\ e-mail: snezana.milicevic@kg.ac.rs \\ ${ }^{3}$ Electric Power Industry of Serbia, e-mail: xenija26@gmail.com
}

\begin{abstract}
Purpose of this paper is to determine how students perceive the image of their faculty on social networks, but also to analyse their experience and attitudes towards faculty social media strategy. The research was implemented using descriptive statistic techniques, as well as non-parametric tests such as Mann-Whitney U Test, Kruskal-Wallis H Test and Spearman's Rho. The most common source of information when it comes to enrolment to faculty is word of mouth, while social media have a significantly lower credibility. During their schooling the respondents have most confidence in the official website, and far less in social networks. Such findings signalize the necessity of creating an adequate digital marketing strategy that can significantly improve the perceived faculty image. Positive perception of the image is fundamental for understanding the process of searching for and selection of the faculty, especially since the results have shown that the students do not value highly the image their faculties have on social networks. Positive perception of faculty image mostly depends on promotion strategy on Facebook and Instagram, and far less on Linkedln and Twitter. In addition, students value more the image of the faculty whose social network profile they follow and, in a case, when they are followed back. No correlation was found between faculty image and gender, age or average grade. Therefore, we can conclude that social networks are very important in creating positive image and thanks to new technology, they are a promising solution for differentiation from competition in digital space.

Keywords: student's perception, attitudes, faculty image, social networks, tourism and hospitality faculty.
\end{abstract}

\section{Introduction}

Over the last few years, the higher education sector has experienced accelerated market changes, which has led to the development of numerous customer-driven marketing strategies as well as recruitment processes. These changes primarily occur thanks to the millennial generation, who know and use the internet very well (Hesel and Williams, 2009) demonstrating a strong need and desire to connect with other people and cooperate with them (Lindbeck and Fodrey, 2010). Smith (2011) as well as Milićević, Petrović, and Đorđević, (2020) state that the competitiveness of higher education institution should derive from the opportunities students have to access all the information they need very quickly and easily.

Kaplan and Mazurek (2018) define social media as a group of Internet-based applications that allow the users to exchange the content and to participate in interactive communication. Social media provide a very easy way for organizations to connect with the existing and future clients, as well as other interested stakeholders (Nyangau and Bado, 2012; Minocha, 2009). Social media are especially important marketing tools for higher education institutions (HEI) (Constantinides and Zinck Stagno, 2011). Higher education institutions mostly use the following social media: social networks (such as Facebook and Instagram), web platforms for online video sharing (such as YouTube and Snapchat), blogs (like Twitter), business-oriented online services (such as Linkedln), Internet forums, etc. (Mazurek, Korzyński and Górska, 2019). In particular social media are becoming very important for students (Tezer, et al., 2017). Eldegwy, Elsharnouby and Kortam (2018) state that social media enable interactive communication between students, as well as between the students and the employees of higher education institutions, which overall contributes to

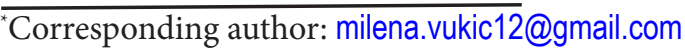


their positive experience during studies. For example, existing university students share information and their experiences about studying in social media platforms, which may contribute significantly to new students (De Silva and Rossi, 2018). Facebook is the example of the social network that is most accepted by students as it provides them with easy and fast communication with the higher education institution (Roblyer et al., 2010).

Numerous authors define the organizational image in differentways. According to Küçüksüleymanoğlu (2015) organizational image is the sum of thoughts and perceptions created in the minds of key stakeholders about the organization and its constitutive elements. Organizational image refers to people's impressions of an organization and is defined as people's loose structures of knowledge and beliefs about an organization (Lievens, 2017). Van Riel and Fombrun (2007) state that organizational image comprises of all the interpretations the stakeholders make about an organization. Image is an immediate stakeholder perception founded on impressions toward the organization (Heding et al., 2009; Huang and Lien, 2012). In general, the definitions of organizational image take into consideration a cognitive element based on the group of perceived beliefs or attributes of the organization (Pérez and Torres, 2017).

In scientific publications, one can find research by numerous authors regarding the organizational image of higher education institutions. Organizational image of a higher education institution is a perceived image that the public has toward the institution according to their interests and personal experiences (Nguyen and LeBlanc, 2001). Organizational image is an important issue for many higher education institutions due to the competitive environment that conditions a significantly higher level of service quality (Pérez and Torres, 2017). It is an important factor to attract and retain the best domestic and foreign students and prestigious professors (Drydakis, 2015; Faham et al., 2017; Kheiry et al., 2012; Polat, 2011). In other words, the institutional image has a direct impact on students' value perception, satisfaction and loyalty and it is a very important tool to attract new students (Brown and Mazzarol, 2009; Elsharnouby, 2015).

To create a successful image of a higher education institution, it is very important to consult the key stakeholders, and accordingly choose the most appropriate communication strategy (Küçüksüleymanoğlu, 2015). Numerous authors in their research have analyzed relationships among student's perception and image of higher education institutions (Alves and Raposo, 2010; Pampaloni, 2010; Sung and Yang, 2008). Küçüksüleymanoğlu (2015) states that the students' perceptions of the image of the faculty depend on their gender, their socio-cultural activities and their achievements during studies. The results of the research conducted at Australian universities show that the image of the faculty is of great importance for the students, regardless of the students' age (Brown and Mazzarol, 2009).

Institutional image is usually created as the result of the interplay between two elements, as an integration of the information presented by the higher education institution and the communication instruments (Mackelo and Drūteikienè, 2010). Some researchers indicate that the organizational image of a higher education institution consists of a great number of factors, such as: previous reputation, facilities, courses popularity, atmosphere, tuition fees, professors, theoretical-practical approach, communication between students and professors, number of students and marketing efforts in the online environment (Fransen and Van Rompay, 2011; Galiniené et al. 2009; Štefko et al., 2015).

According to Simoes and Soares (2010) the Internet has significantly changed the way students obtain information about higher education institutions. Communication becomes more virtual, digital, online, but its purpose remains the same (Garabinović, 2019). Online environment offers higher education institutions various marketing strategies that facilitate the placement of a lot of information and enable two-way communication with the existing and future students (Alexa, Alexa, and Stoica, 2012). A welldesigned institution's website leads to a positive perception toward the higher education institution, i.e., becomes a dynamic marketing tool to attract students (Foroudi et al., 2019).

The main objective of the study is to determine students' perception towards the image of the faculty on social networks. Also, this paper examined their attitudes and experience regarding faculty social media strategy. Beside this, in the research focus, is impact of social networks on recruiting new students and comparison of faculty usage of traditional communication with a communication trough social network.

\section{Literature review}

In the last few years higher education (booth vocational and academic ones) has become one of the fastest-growing service sectors (Alwi and Kitchen, 2014) which has contributed to the spread of knowledge and the development of society (Council of Europe, 2019). This trend is followed by more usage of social networks for reaching out new students as well as by dominating digital marketing strategies 
over traditional ones (Bamberger, Bronshtein, and Yemini, 2020). Benefits that these networks offer are numerous. First of all, lower expenditures of promotion, high effectiveness in communication and reaching audience, institution comparison based on their online image, a large number of users, interactivity, adaptiveness and availability (Bednar, 2013; Kelleher and Sweetser, 2012; Kumar and Nanda, 2019; Kumar and Nanda, 2020; Manca and Ranieri, 2016). Social networks made new relationships with future and existing students, throughout fostering their engagements through likes, comments, and shares of a post (Bamberger, Bronshtein and Yemini, 2020; Brech et al. 2017; Kelly, Kerr, and Drennan, 2010; Pucciarelli and Kaplan, 2016). Designing scalable learning system based on student preferences is the future of HEl's (Kuzmanovic et al. 2019).

Barnes and Matson (2010) investigated usage of social media in U.S. higher education and they found that the most popular is Facebook, which they use for attracting students, while Twitter was on the second place. Slover-Linett and Stoner (2011) analysed data collected from 1,000 universities worldwide, and concluded that most institutions used Facebook (94\%), on the second place were Twitter, Linkedln, and/or YouTube. Kuzma and Wright (2013) explored usage of social networks among 90 universities in Africa, Asia and Europe, where results indicate Facebook and Linkedln are the most represented in all locations, especially Facebook with $77 \%$ to $94 \%$ usage for marketing purpose, while others (Twitter, MySpace and YouTube) vary in different countries. Most of the universities are using predominantly global social networks except in China, where the market is dominated by local ones. Beside growing number of networks, Peruta and Shields (2018), consider that Facebook is still the most powerful tool that can provide significant return on HE marketing investment through user generated content posted at right time. Research study of state faculties in Serbia and their visibility on social media has shown that they do not have clear social media strategy and that Facebook is the most often used channel (Stević, Vujičić, and Lalić, 2017). The latest investigation of Serbian HEI, has also shown the lack of usage of Linkedln and Twitter, which may indicate that not all faculties have accounts on these networks (Vukić and Vukić, 2019).

Beside their primary function such as communication, social networks can be a very powerful tool for teaching and learning purposes (Dyson et al., 2015; Ivanović et al., 2018; Kumar and Nanda, 2020; Radovanović, Hogan, and Lalić, 2015; Tess, 2013). In this respect, they foster creativity, discussions, peer learning, new learning experience, constructive feedback (Kumar and Nanda, 2020) and play a vital role in lifelong learning (Duggan et al., 2015). Social networks throughout digital lecture provide opportunities of unlimited access to extensive resources of knowledge (Powers et al., 2012), development of distance learning and open educational resources (McDougall, Readman, and Wilkinson, 2012). This way of interaction, allows students to feel more connected with university and their colleagues, with tendency to become alumni who will create a strong ecosystem.

Quality HEl's services have a positive impact on students' satisfaction, which will affect their profitability (Duque, 2014). Therefore, it is very important to create an adequate brand image on social networks that will reflect all values that they offer. Furthermore, with an adequate image, it is much easier to attract international students and key stakeholders (Pucciarelli and Kaplan, 2016). This conclusion complements Merrill (2011) who states that the use of social networks improves promotion of institution, distribution of information, recognition of their brand, engagement of potential students, and valuable metrics and competitor practices. An adequate promotion of university brand on social networks can positively affect students' decision-making process (Huynh and Nguyen, 2015) and also determine identities of all stakeholders such as prospective students, current students, graduates, and companies (Lafuente Ruiz de Sabando, Forcada Sainz, and Zorrilla Calvo, 2018). It is very important that students actively participate in the value creation process for brand image and reputation, as they have a more positive attitude toward the university and are more satisfied with their customer journey which brings more attachment to the university (Foroudi et al., 2019). Study conducted by Vogler (2020) shows that despite the crisis in journalism, news media provide credible knowledge and social media represent trustable sources for independent information about science.

We can retrieve few conclusions from previous literature review. Most of the researches have focused on aspects such as: learning and teaching possibilities through social networks; social media strategies, university brand image on social media and students' satisfaction. Moreover, it can be concluded that HEls marketing and recruiting strategy cannot be imagined without social networks, especially Facebook, which is the most popular among students from all over the world. In addition to promotion, social networks enhance university prestige and status, which particularly affects international students, whose attraction can increase profitability. However, the main conclusion is, that there is lack of knowledge about how HEl's image on social media affects students' interest for enrolment, and authors found no previous research study regarding students' perception of HEI image on social networks in Serbia. Therefore, the results of this study provide a better insight into what affects the perception of the 
image of the faculty on social networks and it can be used for making the image of the faculty better.

\section{Materials and Methods}

An empirical study was conducted to explore the students' perception of faculty image on social networks, as well as their experience and attitudes toward faculty social media strategy. The study sample consisted of students who studied hotel management and tourism courses at the University of Belgrade and the University of Novi Sad, which included four faculties. The main research instrument in this study was an online questionnaire, which was distributed through faculties' Facebook groups during summer semester of the 2019/20 academic year.

The questionnaire was organized in three sections. The first section covered questions related to the demographics of the respondents. The second section was related to their experience and attitudes towards the faculty social media strategy. Statements regarding students' perceptions of the faculty image on social networks were included in the third section. Students evaluated statements on a five-point Likert scale, where 1 stands for "strongly disagree", while 5 stands for "strongly agree". The research plan was adopted from the previous study of the impact of social networks on the recruitment of college students conducted by Vukić and Vukić (2019), but this study provides more detailed insight into the significance of social networks for creating positive image of $\mathrm{HEl}$.

Quantitative research methods were applied and data analysis was done using IBM SPSS 25.0 for Windows software. Descriptive statistics was used for computing mean and standard deviation of all items. Mann-Whitney U Test was used, in order to test the equality of Mean Rank in two independent samples. Spearman's Rho was used in order to measure the strength of correlation between two variables that did not have a normal distribution. Kruskal-Wallis $\mathrm{H}$ Test was applied. In order to obtain statistically significant evidence, that there is a difference in Mean Rank between more than two groups of independent variables. Chrombach Alpha reliability test was used to check the internal consistency of the statements used for measuring summed scale of perception. These non-parametric analyses were conducted, because Shapiro-Wilk's test $(p<0.01)$ showed that criteria for normally distributed data were not met. The results of the study should answer questions such as: 1) What are students' experience and attitudes toward faculty social media strategy; 2) What is students' perception about the image of the faculty on social networks; 3 ) Is there a correlation between the faculty image on social networks and attraction of new students; 4) Are there statistical differences in students' perception about the image of the faculty across their different characteristics e.g. sex, year of the study, content which they pay the most attention to when they visit a faculty's profile. 


\section{Results and Discussion}

A total of 270 students completed the questionnaire. Demographic data show that the number of female respondents was slightly higher than the number of male respondents. The average age of the respondents was $22.18(S D=2.27$ ) while average grade during studies of the students from the sample was $8.17(S D=0.62)$. More detailed information about demographics of the sample is shown in Table 1.

Table 1

Sample characteristics

\begin{tabular}{|c|c|c|c|c|}
\hline & Frequency & & Percent & \\
\hline \multicolumn{5}{|l|}{ Sex } \\
\hline male & 132 & & $48.9 \%$ & \\
\hline female & 138 & & $51.1 \%$ & \\
\hline Total & 270 & & $100 \%$ & \\
\hline Year of study & Frequency & & Percent & \\
\hline first & 30 & & $11.1 \%$ & \\
\hline second & 44 & & $16.3 \%$ & \\
\hline third & 66 & & $24.4 \%$ & \\
\hline forth & 62 & & $23.0 \%$ & \\
\hline only exams left & 32 & & $11.9 \%$ & \\
\hline graduated & 36 & & $13.3 \%$ & \\
\hline \multirow[t]{2}{*}{ Total } & 270 & & $100 \%$ & \\
\hline & Minimum & Maximum & Mean & Std. Deviation \\
\hline Average grade & 7 & 10 & 8.17 & 0.62 \\
\hline Average age & 18 & 31 & 22.18 & 2.27 \\
\hline
\end{tabular}

Regarding the way of obtaining information when enrolling in faculty, the students mostly made use of word-of-mouth propaganda (41.1\%), followed by personal visits to the faculty $(24.1 \%)$, the third source of information being their high-school teachers (13.7\%), the fourth social networks (12.6\%), whereas they were least informed through the visits of the faculty representatives $(5.2 \%)$ or propaganda in the media (TV, radio, magazines, newspapers). Insufficient use of social networks for obtaining information could indicates that faculties' social media profiles don't give enough real time information about enrolment. Prospective students are easily bored searchers, that's why faculties will need to transition from traditional communication to content that is visually appealing and psychologically intrigues. Sharing stories could make stronger connections with the faculty, and help students in decision making process. Live features could engage current and potential customers by sharing faculty events in real-time, which can bring them a real sense of what student's life is like from a student's point of view. Good social media strategy gives new opportunities for faculties and even brought personality back into a digital world. However, all this, open research gap for additional examination of such a poor rating of social network.

The respondents think that the most important social network in terms of attracting new students is Facebook (mean $=3.84$ ), followed by Instagram (mean= 3.64), whereas the less important are Linkedln (mean $=2.31$ ) and Twitter (mean $=2.16)$. Such a small significance of Linkedln and Twitter may be an indicator of the infrequent use of these social networks, which should be further investigated.

The results have shown that a vast majority of students follow their faculties on social networks (81.1\%) whereas only $18.9 \%$ do not. This finding leaves plenty of opportunities for faculties in Serbia to exploit the potential of social networks and apply a new branding concept, which will positively affect their reputation and consequently make it easier for the students to differentiate between competitors. However, the faculties follow a very small number of students (24.1\%); that way, the faculties are missing the information on the contents students post and the ones they react to, thus losing the most important purpose of social networks - interactivity.

Students check the faculties' social network profiles mostly in order to get informed $(96.3 \%)$, very few of them for educational purposes $(0.7 \%)$ and for fun $3 \%$. Such information may indicate that other contents are posted to a lesser extent, and therefore it is important to check their preferences towards the contents they would like to see. However, in order for the faculties to have diverse content on social 
networks, the faculty itself has to reshape its own business model in terms of offering new educational package that will be developed together with the students and stakeholders, creating new values.

The source of information most trusted by the students when it comes to notification during their studies is the official website $(80.4 \%)$, as expected; their professors come in second (8.1\%), fellow students third $(7 \%)$, faculty profile on social networks fourth $(2.6 \%)$, whereas other sources come in last $(1.9 \%)$. This may indicate the fact that the notifications on social networks are not regularly updated, or that they are considerably late in doing so compared to the website, so it is safe to say that the faculty do not have a clear social media strategy.

As for the students' perception related to the contents on the social networks of the faculty, most of them pay the most attention to the text $(68.1 \%)$, half as many to the picture $(30.7 \%)$, and the least of them pay attention to the video $(1.1 \%)$.

\section{Students' perception of faculty image on social networks}

Except from the students' experience and attitudes towards the faculties' social media strategy, this study investigated students' perception of faculty image on social networks. For this purpose, a new summary scale was designed, consisting of individual items of students' attitudes towards the image on social media. The theoretical range of the scale ranges from 1 (denoting the perception that the faculty image on social networks is not satisfactorily) to 5 (image of the faculty on social networks is highly satisfactory), whereas the empirical ranges from 1.11 to 5 (Table 2). The average value of the students' responses on the summary scale is $3.12(S D=0.82)$, showing that the students consider the image of the faculty on social networks not indeed satisfactory. The distribution of the students' responses in Table 3 statistically significantly deviates from normal $(p<0.01)$; therefore, for the analysis of the students' perception of faculty image on social media, non-parametrical tests shall be applied (Spearman's rank correlation coefficient, Mann-Whitney and Kruskal-Wallis test). The new summary scale of faculty image on social networks indicates a satisfactory level of reliability (Cronbach's Alpha> 0.7), which can be seen in Table 2. All further analysis is conducted with summarized scale.

Table 2

Reliability of summary scale of faculty image on social networks

\begin{tabular}{ccccccccc}
\hline & $\begin{array}{c}\text { Minimum of } \\
\text { scale }\end{array}$ & $\begin{array}{c}\text { Maximum of } \\
\text { scale }\end{array}$ & $\begin{array}{c}\text { Empiric } \\
\text { Minimum }\end{array}$ & $\begin{array}{c}\text { Empiric } \\
\text { Maximum }\end{array}$ & Mean & $\begin{array}{c}\text { Std. } \\
\text { Deviation }\end{array}$ & $\begin{array}{c}\text { Cronbach's } \\
\text { Alpha }\end{array}$ & $\begin{array}{c}\text { Sig - } \\
\text { Shapiro-Wilk }\end{array}$ \\
\hline $\begin{array}{l}\text { Faculty } \\
\text { Image }\end{array}$ & 1 & 5 & 1.11 & 5 & 3.12 & 0.82 & 0.84 & 0.03 \\
\hline
\end{tabular}

The summary scale of the image consisted of the responses expressed through the level of agreement with the nine statements, such as: 1 . quality of enrolment information on faculty social media profile is very high; 2 . image of faculty on social networks can have positive impact on my employment; 3. social media profile of my faculty is interesting; 4. faculty social network profile offers high quality information about current information necessary for students; 5 . social network accounts give enough information about internship opportunities; 6 . social network accounts offer educational content; 7 . social network accounts give detailed information about the enrolment of new candidates; 8 . professors should use more social network for communication with students; 9. social networks have advantages in communication with students in comparison to traditional ways of communication.

It can be seen in Table 3 that the students expressed the highest degree of agreement with the statement that the profile of their faculty on social networks provides detailed information on the enrolment of new candidates; on the other hand, they least agreed with the statement that the communication with students through social networks should have an advantage over traditional means of communication. 
Vukić et al. (2021). Students' perception and attitudes toward faculty image on social networks, International Journal of Cognitive Research in Science, Engineering and Education (IJCRSEE), 9(1), 63-74.

Table 3

Students' attitudes towards the faculty image on social networks

\begin{tabular}{ccccc}
\hline statement & means & St. dev & Min & Max \\
\hline 1 & 3.37 & 1.183 & 1 & 5 \\
2 & 3.26 & 1.216 & 1 & 5 \\
3 & 2.91 & 1.129 & 1 & 5 \\
4 & 3.43 & 1.131 & 1 & 5 \\
5 & 2.94 & 1.245 & 1 & 5 \\
6 & 3.06 & 1.134 & 1 & 5 \\
7 & 3.53 & 1.263 & 1 & 5 \\
8 & 3.00 & 1.462 & 1 & 5 \\
9 & 2.54 & 1.415 & 1 & 5 \\
\hline
\end{tabular}

Spearman's rank correlation coefficient (Table 4) showed a statistically significant positive correlation between the faculty image on social networks and attracting new students through them. The more positive the image on social networks, the greater the number of students who are interested in enrolling in faculty. The positive image of the faculty on Facebook $(0.44, p<0.01)$ is mostly related to attracting students, somewhat less is related with Instagram $(0.33, p<0.01)$ and Twitter $(0.26, p<0.01)$, and much less with Linkedln $(0.12, p=0.05)$.

Table 4

The correlation between the faculty's image, students' age, positive impact of social networks on re-cruiting new students and perception of the importance of a different social network

\begin{tabular}{|c|c|c|c|c|c|c|}
\hline & & & Facebook & Instagram & Linkedln & Twitter \\
\hline \multirow{6}{*}{ Spearman's rho } & \multirow[t]{3}{*}{ Faculty image } & $\begin{array}{l}\text { Correlation Co- } \\
\text { efficient }\end{array}$ & $0.44^{* *}$ & $0.33^{* *}$ & $0.12^{*}$ & $0.26^{* \prime}$ \\
\hline & & Sig. (2-tailed) & 0.00 & 0.00 & 0.05 & 0.00 \\
\hline & & $\begin{array}{l}\text { Correlation Co- } \\
\text { efficient }\end{array}$ & 0.02 & 0.02 & $0.32^{*}$ & 0.05 \\
\hline & Age & Sig. (2-tailed) & 0.77 & 0.81 & 0.00 & 0.41 \\
\hline & $\begin{array}{l}\text { Promotion on social } \\
\text { networks have positive }\end{array}$ & $\begin{array}{l}\text { Correlation Co- } \\
\text { efficient }\end{array}$ & $0.49^{* *}$ & $0.31^{* *}$ & $0.26^{*}$ & $0.23^{* *}$ \\
\hline & $\begin{array}{l}\text { impact on recruiting } \\
\text { new students }\end{array}$ & Sig. (2-tailed) & 0.00 & 0.00 & 0.00 & 0.00 \\
\hline
\end{tabular}

${ }^{\star \star}$. Correlation is significant at the 0.01 level (2-tailed).

*. Correlation is significant at the 0.05 level (2-tailed).

Positive correlation was also found between age and perception of attracting new students via Linkedln $(0.32, p<0.05)$, i.e., older students consider Linkedln important for attracting new students, which may indicate that these are mostly respondents who are employed, which is why they consider this network attractive. The perception of the importance of other networks for student enrolment was not related to the age of the respondents ( $p>0.01)$. There is a statistically significant connection between promotional activities on social networks and the attracting of new students. Namely, more intensive campaigns on Facebook $(0.49, p<0.01)$ and Instagram $(0.31, p<0.01)$ are associated with greater interest in enrolment, while higher promotional activities on Linkedln $(0.26, p<0.01)$ and Twitter $(0.23, p<0.01)$ affect students but to a lesser extent.

Statistically significant correlation was not obtained between the faculty image and the age of respondents $(0.03, p>0.05)$ and between image and the average grade $(-0.04, p>0.05)$. The Average grade does not show a statistically significant correlation with the attitude that promotion on social networks positively impact recruiting students $(0.01, p>0.05)$, or with the perception of the significance different 
social networks (Facebook, Instagram, Linkedln and Twitter) for recruiting new students ( $p>0.05$ ).

Mann-Whitney U Test results confirmed statistically significant differences in the level of faculty image perception on social networks between the students who follow the faculty accounts and those who do not (3882.000, $p<0.01)$, and between students who are followed by the faculty accounts and those who are not $(5281.000, p<0.01)$ as shown in Table 5 . Students who followed their faculty on social networks and those who are followed back, perceived faculty image more positively than the other one.

Mann-Whitney $U$ Test indicates no significant difference in the level of expression of a positive image of the faculty on social networks, between the male and female students (9092.500, $p>0.05)$. Results of Kruskal Wallis Test $(8.400, p>0.05)$ suggest no significant difference in perceived image between students of different year of study $(8.400, p>0.05)$ and depends on the content they pay the most attention to, when they visit a social network profile (picture, text, video) $(0.765, p>0.05)$. Also, same test suggests no significant difference in perceived image depends on purpose of checking the profile of the faculty (3.836, $p>0.05)$; the way they obtained information on the faculty they enrolled in $(3.297, p>0.05)$ and the most trusted source they used to obtain information on the faculty $(4,635, p>0.05)$.

Table 5

Students' faculty image perception depending on whether they are following faculty account, and whether they are followed back on social networks

\begin{tabular}{ccccc}
\hline Question & Mean rank & Mann-Whitney U & Z & Asymp. Sig. (2-tailed) \\
\hline Do you follow faculty on social networks & & & & \\
\hline Yes & 143.27 & $\mathbf{3 8 8 2 . 0 0 0}$ & -3.394739 & $\mathbf{0 . 0 0}$ \\
\hline No & 102.12 & & & \\
\hline $\begin{array}{c}\text { Are you followed back by faculty on social } \\
\text { networks }\end{array}$ & & & & $\mathbf{0 . 0 1}$ \\
\hline Yes & 156.75 & $\mathbf{5 2 8 1 . 0 0 0}$ & -2.522 & \\
\hline No & 128.76 & & & \\
\hline
\end{tabular}

\section{Conclusions}

The study aimed to investigate how students perceive the image of their faculty on social networks, but also to analyse their experience and attitudes towards faculty's social media strategy. Trough empirical research we gathered information which can contribute $\mathrm{HEl}$ in creating adequate communication strategy with prospective and current students. Also, based on results it is possible to make interactive brand, which will facilitate a students' journey towards pursuing a graduate degree. Creating content based on the students' needs it is possible to turn social networks into search engines which will answer all the necessary questions, from looking for financial costs and career opportunities, to faculty projects.

Much research has been done on usage of social networks in $\mathrm{HEl}$, but most of these studies have addressed the topics such as learning and teaching possibilities, impact of HEl brand image on students' satisfaction, and decision-making process (Duque, 2014; Kuzma and Wright, 2013; Kumar and Nanda, 2020; Pucciarelli and Kaplan, 2016). Despite large scope of papers, there is lack of knowledge about how HEl's image on social media affects students' interest for enrolment.

The results of this study have shown that students primarily pay attention to the text, when it comes to HEl social network profiles. Such results can be considered logical, as the primary purpose of faculty social network profile is informative communication. However, in order to create a recognizable image, it is also important to make use of transformative communication implying the values offered to students, and therefore the institutions of higher education must carefully design various contents, as the stimuli such as text in an advertising message require more attention to be understood than a picture or a video. Due to the rapid adaptation to one type of stimuli, in order to attract the attention of current as well as potential students and other stakeholders, it is necessary to use other means of gaining attention such as colours, sounds, videos or various types of novelties, so that it could be managed. That way, it is possible to create an advertising message that contains essential information but at the same time manages to get students spend more time on social network profile of the faculty, in order to convey to them clearly the values they are offered.

When it comes to the enrolment information, research result showed that sources of the greatest 
credibility are friends, acquaintances, forums, i.e., all those who are not paid to promote the college. Visits to the faculty instil great confidence during enrolment, due to the expertise i.e., professional knowledge of the professors or members of staff with whom students communicate. Social networks and media are the least likable sources in these situations, and therefore the focus should be on the development of ideas and creative strategies of communication that will help a better positioning of the faculty relative to competitors in virtual space.

Exploring the perception of the faculty's image on social networks, findings showed that the respondents think that Facebook and Instagram have the greatest influence on a positive image. This is in line with the findings of Slover-Linett and Stoner (2011) as well as Peruta and Shields (2018). Therefore, the promotional activities should be directed towards these networks. It was discovered that the perception of the faculties on social networks does not depend on the gender, year of study, the content students visited on social media profile or the way of obtaining information about enrolment.

The positive image is rather related to whether the students follow the faculty's social media profiles and whether they are followed back. This can only indicate that the students place great value on social networks i.e., that the social networks are important to them, which should be further examined.

This paper makes a number of contributions, but the most significant ones are:

- Research about students' perception and attitudes toward HEl image on social networks is extended and the body of knowledge how digital faculty brand image can attract prospective students is enriched.

- Students' perception and attitudes toward faculty social media profile were identified.

- A new social media strategy is proposed according obtained results.

This study has certain limitation. First limitation is that sample doesn't include private faculties which social media strategy could be quite different from our sample. The second limitation is the reliance on respondents who studied hotel management and tourism courses when making conclusion about the image of faculty on social networks. Also, students of higher vocational schools are not surveyed, so we can't compare their image perception with academic one. And the last one, is the fact that survey is conducted in Republic of Serbia, so the results could be specific to this territory only. Future research could focus on the collection of more diversification of respondents by their fields of education, countries and ownership structure.

\section{Acknowledgements} this paper.

The authors are grateful to all participants in the research and colleagues for support in creation of

\section{Conflict of interests}

The authors declare no conflict of interest.

\section{References}

Alexa, E. L., Alexa, M., \& Stoica, C. M. (2012). The use of online marketing and social media in higher education institutions in Romania. Journal of Marketing Research \& Case Studies, 2012 (1)..https://doi.org/.5171/2012.721221

Alves, H., \& Raposo, M. (2010). The influence of university image on student behaviour. International Journal of Educational Management 24(1): 73-85. https://doi.org/10.1108/09513541011013060

Alwi, S. F. S., \& Kitchen, P. J. (2014). Projecting corporate brand image and behavioral response in business schools: Cognitive or affective brand attributes?. Journal of Business research, 67(11), 2324-2336. https://doi.org/10.1016/j. jbusres.2014.06.020

Bamberger, A., Bronshtein, Y., \& Yemini, M. (2020). Marketing universities and targeting international students: a comparative analysis of social media data trails. Teaching in Higher Education, 25(4), 476-492. https://doi.org/10.1080/13562517. 2020.1712353

Barnes, N. G., \& Mattson, E. (2010). Social media and college admissions: Higher-ed beats business in adoption of new tools for third year. University of Massachusetts-Dartmouth Center for Marketing Research. Retrieved from http://www. umassd.edu/cmrl

Bednar, J. (2013). Colleges increasingly rely on social media to interact with students and Alumni. Business West. Retrieved from http://businesswest.com/blog/two-way-street/

Brech, F. M., Messer, U., Vander Schee, B. A., Rauschnabel, P. A., \& Ivens, B. S. (2017). Engaging fans and the community in social media: Interaction with institutions of higher education on Facebook. Journal of Marketing for Higher Education, 27(1), 112-130. https://doi.org/10.1080/08841241.2016.1219803

Brown, R. M., \& Mazzarol, T. W. (2009). The importance of institutional image to student satisfaction and loyalty within higher education. Higher education, 58(1), 81-95. https://doi.org/10.1007/s10734-008-9183-8 
Vukić et al. (2021). Students' perception and attitudes toward faculty image on social networks, International Journal of Cognitive Research in Science, Engineering and Education (IJCRSEE), 9(1), 63-74.

Constantinides, E., \& Zinck Stagno, M. C. (2011). Potential of the social media as instruments of higher education marketing: A segmentation study. Journal of marketing for higher education, 21(1), 7-24. https://doi.org/10.1080/08841241.2011 .573593

Council of Europe, (2019). Retrieved December 12, 2020, from https://www.coe.int/en/web/higher-education-and-research/ european-higher-education-area

Council of the European Union. (2019). Resolution on further developing the European Education Area to support futureoriented education and training systems. Retrieved September 26, 2020, from https://data.consilium.europa.eu/doc/ document/ST-13298-2019-INIT/en/pdf

De Silva, M., \& Rossi, F. (2018). The effect of firms' relational capabilities on knowledge acquisition and co-creation with universities. Technological Forecasting and Social Change, 133, 72-84. https://doi.org/10.1016/j.techfore.2018.03.004

Drydakis, N. (2015). Economics applicants in the UK labour market: University reputation and employment outcomes. International Journal of Manpower, 36(3),296-333. https://doi.org/10.1108/IJM-02-2014-0061

Duggan, M., Ellison, N. B., Lampe, C., Lenhart, A., \& Madden, M. (2015). Demographics of key social networking platforms. Pew Research Centre, 9. Retrieved from www.pewinternet.org/2015/01/09/demographics-of-key-social-networkingplatforms2/

Duque, L. C. (2014). A framework for analysing higher education performance: students' satisfaction, perceived learning outcomes, and dropout intentions. Total quality management \& business excellence, 25(1-2), 1-21. https://doi.org/10. 1080/14783363.2013.807677

Dyson, B., Vickers, K., Turtle, J., Cowan, S., \& Tassone, A. (2015). Evaluating the use of Facebook to increase student engagement and understanding in lecture-based classes. Higher Education, 69(2), 303-313. https://doi.org/10.1007/ s10734-014-9776-3

Eldegwy, A., Elsharnouby, T. H., \& Kortam, W. (2018). How sociable is your university brand? An empirical investigation of unversity social augmenters' brand equity, International Journal of Educational Management, 32(5), 912-930. https:// doi.org/10.1108/lJEM-12-2017-0346

Elsharnouby, T. (2015), Student co-creation behaviour in higher education: the role of satisfaction with the university experience, Journal of Marketing for Higher Education, 25(2), 238-262. https://doi.org/10.1080/08841241.2015.1059919

Faham, E., Rezvanfar, A., Mohammadi, S. H. M., \& Nohooji, M. R. (2017). Using system dynamics to develop education for sustainable development in higher education with the emphasis on the sustainability competencies of students. Technological Forecasting and Social Change, 123, 307-326. https://doi.org/10.1016/j.techfore.2016.03.023

Foroudi, P., Yu, Q., Gupta, S., \& Foroudi, M. M. (2019). Enhancing university brand image and reputation through customer value co-creation behaviour. Technological Forecasting and Social Change, 138, 218-227. https://doi.org/10.1016/j. techfore.2018.09.006

Fransen, M. L., \& Van Rompay, T. J. (2011). Living Brands: Consumer Reactions toward Online Experienced-based Marketing Communication. In Advances in Advertising Research, 2, 311-324. Gabler. https://doi.org/10.1007/978-3-8349-68548 820

Galinienè, B., Miškinis, A., Marčinskas, A., \& Drūteikienè, G. (2009). The impact of study quality on the image of a higher education institution. Informacijos mokslai, 48, 68-81. Retreived from https://etalpykla.lituanistikadb.It/object/LT-LDB0001:J.04 2009 1367167976637/J.04 2009 1367167976637.pdf

Garabinović, D. (2019). Online marketing promotion of local tourism organizations: The analysis of the situation in Moravica administrative district. Менацмент у хотелијерству и туризму, 7(1), 71-81. https://doi.org/10.5937/ menhottur1901071G

Heding, T; Knudtzen, C. F., \& Bjerre, M. (2009). Brand Management: Research Theory and Practice. USA: Routledge Press

Hesel, R. A., \& Williams, R. C. (2009). Social networking sites and college-bound students. Student Poll, 7(2), 1-8.

Huang, C., \& Lien, H. (2012). An empirical analysis of the influences of corporate social responsibility on organizational performance of Taiwan's construction industry: Using corporate image as a mediator. Construction Management and Economics, 30, 263-275. https://doi.org/10.1080/01446193.2012.668620

Huynh, T., \& Nguyen, N. (2015). Communicating university brand via social media: case: communicating Lahti University of Applied Sciences brand to international students using social media. Retrieved from http://www.theseus.fi/ handle/10024/98361

Ivanović, M., Milićević, A. K., Aleksić, V., Bratić, B., \& Mandić, M. (2018). Experiences and perspectives of Technology enhanced learning and teaching in higher education-Serbian case. Procedia Computer Science, 126, 1351-1359. https://doi. org/10.1016/j.procs.2018.08.086

Kaplan, A.M., \& Mazurek, G. (2018). Social Media: State of the Art and Research Agenda. In B. Mierzejewska, J. Jung, \& A. Albarran (Eds.), , Handbook of Media Management and Economics (pp. 273-286). London: Routledge.

Kelleher, T., \& Sweetser, K. (2012). Social media adoption among university communicators. Journal of Public Relations Research,24(2),105-122. https://doi.org/10.4018/IJOM.2015070104

Kelly, L., Kerr, G., \& Drennan, J. (2010). Avoidance of advertising in social networking sites: The teenage perspective. Journal of interactive advertising, 10(2), 16-27. https://doi.org/10.1080/15252019.2010.10722167

Kheiry, B., Rad, B. M., \& Asgari, O. (2012). University intellectual image impact on satisfaction and loyalty of students (Tehran selected universities). African journal of business management, 6(37), 10205-10211. https://doi.org/10.5897/ AJBM11.434

Küçüksüleymanoğlu, R. (2015), Organizational ımage perceptions of higher education students, Educational Research and Reviews, 10(20), 2667-2673. https://doi.org/10.5897/ERR2015.2443

Kumar, V., \& Nanda, P. (2019). Social media in higher education: A framework for continuous engagement. International Journal of Information and Communication Technology Education 15(1), 97-108. https://doi.org/10.4018/IJICTE.2019010107

Kumar, V., \& Nanda, P. (2020). Social Media as a Tool in Higher Education: A Pedagogical Perspective. In Handbook of Research on Diverse Teaching Strategies for the Technology-Rich Classroom (pp. 239-253). IGI Global.

Kuzma, J. M., \& Wright, W. (2013). Using social networks as a catalyst for change in global higher education marketing and recruiting. International Journal of Continuing Engineering Education and Life Long Learning, 23(1), 53-66. https://doi. org/10.1504/IJCEELL.2013.051766 
Vukić et al. (2021). Students' perception and attitudes toward faculty image on social networks, International Journal of Cognitive Research in Science, Engineering and Education (IJCRSEE), 9(1), 63-74.

Kuzmanovic, J., Labrovic, A.J., \& Nikodijevic, A. (2019). Designing e-learning environment based on student preferences: conjoint analysis approach. International Journal of Cognitive Research in Science, Engineering and Education. 7(3), 37-47. https://doi.org/10.5937/IJCRSEE1903037K

Lafuente Ruiz de Sabando, A., Forcada Sainz, F. J., \& Zorrilla Calvo, M. P. (2018). The university image: a model of over-all image and stakeholder perspectives. Cuadernos de Gestion, 19(1), 63-86. https://doi.org/10.5295/cdg.160720al

Lievens, F. (2017). Organizational image/reputation. In: S. Rogelberg \& C.L. Reeve (Eds.) The Encyclopedia of Industrial and Organizational Psychology (pp. 1116-1118), $2^{\text {nd }}$ edition. Thousand Oaks, CA: Sage.

Lindbeck, R., \& Fodrey, B. (2010). Using technology in undergraduate admission: A student perspective. Journal of College Admission, 208, 10-17. Retrieved from http://www.nacacnet.org

Mackelo, O., \& Drūteikienè, G. (2010). The Image of a higher education institution, its structure and hierarchical level: the case of the Vilnius university faculty. Ekonomika, 89, 105-121. https://doi.org/10.15388/Ekon.2010.0.972

Manca, S., \& Ranieri, M. (2016). "Yes, for sharing, no for teaching!": Social media in academic practices. The Internet and Higher Education, 29, 63-74. https://doi.org/10.1016/j.iheduc.2015.12.004

Mazurek, G., Korzyński, P., \& Górska, A. (2019). Social Media in the Marketing of Higher Education Institutions in Poland: Preliminary Empirical Studies. Entrepreneurial Business and Economics Review, 7(1), 117-133. https://doi. org/10.15678/EBER.2019.070107

McDougall, J., Readman, M., Wilkinson, P. (2018). The uses of (digital) literacy. Learning, Media and Technology, 43(3): 263279. https://doi.org/10.1080/17439884.2018.1462206

Merrill, N. (2011). Social media for social research: Applications for higher education communications. In Higher education administration with social media. Emerald Group Publishing Limited.

Milićević, S., Petrović, J., \& Đorđević, N. (2020). ICT as a factor of destination competitiveness: The case of the republics of former Yugoslavia, Management \& Marketing. 15(3), 381-392. https://doi.org/10.2478/mmcks-2020-0022

Minocha, S. (2009). Role of social software tools in education: A literature review. Education + Training, 51, 353-369. https:// doi.org/10.1108/00400910910987174

Nguyen, N., \& LeBlanc, G. (2001). Image and reputation of higher education institutions in students' retention decisions. International journal of educational management. https://doi.org/10.1108/EUM0000000005909

Nyangau, J. Z., \& Bado, N. (2012). Social Media and Marketing of Higher Education: A Review of Literature. Journal of the Research Center for Educational Technology, 8(1), 38-51. Retrieved from http://rcetj.org/index.php/rcetj/article/ view/180/264

Pampaloni, A. (2010). The influence of organizational image on college selection: what students seek in institutions of higher education. Journal of Marketing for Higher Education 20(1):19-48. https://doi.org/10.1080/08841241003788037

Pérez, J. P., \& Torres, E. M. (2017). Evaluation of the organizational image of a university in a higher education institution. Contaduría y administración, 62(1), 123-140. https://doi.org/10.1016/j.cya.2016.01.007

Peruta, A., \& Shields, A. B. (2018). Marketing your university on social media: A content analysis of Facebook post types and formats. Journal of Marketing for Higher Education, 28(2), 175-191. https://doi.org/10.1080/08841241.2018.1442896

Polat, S. (2011). The relationship between university students' academic achievement and perceived organizational image. Educational Sciences: Theory \& Practice, 11, 257-262. Retrieved from https://eric.ed.gov/?id=EJ919900

Powers, T., Advincula, D., Austin, M. S., Graiko, S., \& Snyder, J. (2012). Digital and social media in the purchase decision process: A special report from the Advertising Research Foundation. Journal of advertising research, 52(4), 479-489. https://doi.org/10.2501/JAR-52-4-479-489

Pucciarelli, F., \& Kaplan, A. (2016). Competition and strategy in higher education: Managing complexity and uncertainty. Busness Horizons, 59(3), 311-320. https://doi.org/10.1016/j.bushor.2016.01.003

Radovanović, D., Hogan, B., \& Lalić, D. (2015). Overcoming digital divides in higher education: Digital literacy beyond Facebook. New media \& society, 17(10), 1733-1749. https://doi.org/10.1177/1461444815588323

Roblyer, M. D., McDaniel, M., Webb, M., Herman, J., \& Witty, J. V. (2010). Findings on Facebook in higher education: A comparison of college faculty and student uses and perceptions of social networking sites. The Internet and higher education, 13(3), 134-140. https://doi.org/10.1016/j.iheduc.2010.03.002

Simões, C., \& Soares, A. M. (2010). Applying to higher education: information sources and choice factors. Studies in Higher Education, 35(4), 371-389. https://doi.org/10.1080/03075070903096490

Slover-Linett, C., \& Stoner, M. (2011). Succeeding with social media: Lessons from the first survey of social media in advancement. Slover Linett Issue Paper Series, 1-37. Retrieved from https://nextrends.swissnexsanfrancisco.org/wpcontent/uploads/sites/5/2011/03/case_succeeding-with-social-media.pdf

Smith, K. T. (2011). Digital marketing strategies that Millennials find appealing, motivating, or just annoying. Journal of Strategic Marketing, 19(6), 489-499. https://doi.org/10.1080/0965254X.2011.581383

Štefko, R., Fedorko, R., \& Bačík, R. (2015). The role of e-marketing tools in constructing the image of a higher education institution. Procedia-Social and Behavioural Sciences, 175, 431-438. https://doi.org/10.1016/j.sbspro.2015.01.1220

Stević, N., Vuiičić, D., \& Lalić, D. (2017). Visibility of Serbian State Universities on The Internet and Social Media. International Scientific Conference on Industrial System (IS'17). Retrieved June 29, 2020, from https://www.iim.ftn.uns.ac.rs/is17/ papers/90.pdf

Sung, M., \& Yang, S. (2008). Toward the model of university image: The influence of brand personality, external prestige, and reputation. Journal of Public Relations Research 20(4): 357-376. https://doi.org/10.1080/10627260802153207

Tess, P. A. (2013). The role of social media in higher education classes (real and virtual) - A literature review. [online]. Computers in Human Behavior, 29(5), A60-A68. https://doi.org/10.1016/j.chb.2012.12.032

Tezer, M., Taşpolat, A., Sami Kaya, Ömer, \& Fatih Sapanca, H. (2017). The impact of using social media on academic achievement and attitudes of prospective teachers. International Journal of Cognitive Research in Science, Engneering and Education (IJCRSEE), 5(2), 75-82. https://doi.org/10.5937/IJCRSEE1702075T

Van Riel, C. B., \& Fombrun, C. J. (2007). Essentials of corporate communication: Implementing practices for effective reputation management. Routledge.

Vogler, D. (2020). The effects of media reputation on third-party funding of Swiss universities. Journal of Communication Management. https://doi.org/10.1108/JCOM-04-2019-0059 
Vukić et al. (2021). Students' perception and attitudes toward faculty image on social networks, International Journal of Cognitive Research in Science, Engineering and Education (IJCRSEE), 9(1), 63-74.

Vukić, M., \& Vukić, M. (2019). The impact of social media on the recruitment of students by higher education institution. Tourism International Scientific Conference Vrnjačka Banja - TISC, 4(1), 307-326. Retrieved from http://www.tisc.rs/ proceedings/index.php/hitmc/article/view/258 